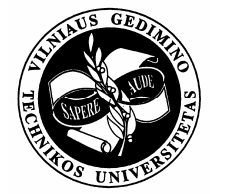

\title{
NUMERICAL MODEL OF THREE-DIMENSIONAL COUPLED WALL STRUCTURES
}

\author{
Czesław Miedziałowski ${ }^{1}$, Tadeusz Chyży ${ }^{2}$, Joanna Krętowska ${ }^{3}$ \\ Institute of Civil Engineering, Biatystok Technical University, \\ ul. Wiejska 45E, 15 -351 Białystok, Poland. E-mail: ${ }^{1}$ Cz.Miedzialowski@kmb.pb.bialystok.pl; \\ ${ }^{2}$ teddy@pb.bialystok.pl; ${ }^{3}$ J.Kretowska@kmb.pb.bialystok.pl \\ Received 26 July 2005; accepted 26 May 2006
}

\begin{abstract}
Three-dimensional description of a building structure taking into consideration the soil structure interaction is a very complex problem; the solution of it is often obtained by the finite-element method. However, this method takes a significant amount of computational time and memory. Therefore an efficient computational model based on the subdivision of the structure into building elements such as wall and floor slab elements, plane and three-dimensional joints and lintels, that could provide accurate results with a significantly reduced computational time, is proposed in this study for the analysis of three-dimensional structures. The examples prove the efficiency and the computing possibilities of the model.
\end{abstract}

Keywords: three-dimensional building elements, super elements, dynamic problem formulation, finite-element method.

\section{Introduction}

Three-dimensional description of building structure taking into consideration soil structure interaction is a very complex problem and solution of this problem is often obtained by the finite element method. The building structure and the subsoil create a uniformly interacting system which can be accurately described only by threedimensional analysis. Such analysis allows not only to design building structures in an efficient way but also to take into account complicate load and soil conditions Fig 1. On the area of Poland, the kinematic loads are caused mostly by mining [1] and road traffic (paraseismic effects), but lately the typical seismic effects have been noticed in north-eastern part of Poland and Lithuania.

The computational model created to solve these problems, which uses classical finite elements, incorporates a)
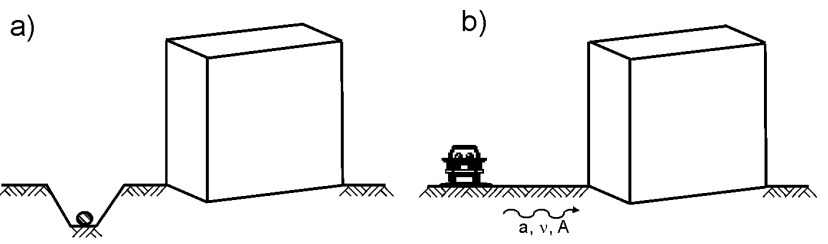

c)

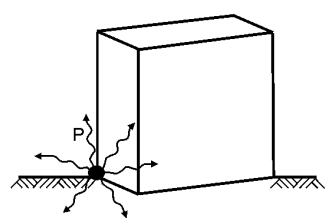

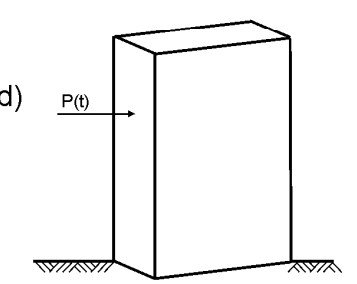

Fig 1. Special loads of building structures: a) changes in subsoil, b) vibrations, c) explosions, d) impact substantial disadvantages as a result of high timeconsuming computations (a high number of degrees of freedom) and extended data processing.

Many building structures are constructed using coupled shear walls or shear wall-frame systems. Therefore much research on efficient analysis of such structures has been undertaken [2-4]. Plane stress elements and beam elements have been used to model the shear wall core and frames. The transition region in which beam and shear walls or frames are interconnected is often the weakest area. In general, wall element is treated in FEM as plane stress element (has two translational degrees of freedom per node) and beam element has three degrees of freedom per node (two translational and one rotational). Due to this reason, many research workers have taken into account the connections between shear wall and beam or shear wall and frame [4-7].

The paper presents an efficient three-dimensional computational model (called MQDES) based on subdivision of the structure into building elements such as wall and floor slab elements, plane and three-dimensional joints and lintels, that could provide accurate results with significantly reduced computational time. The theory of Timoshenko-type beam has been used to describe wall and floor strips but the compression and twisting have been added to the classical formulation. The description allows to obtain internal forces for every strip what can be very useful in the engineering practice (designing process).

Proposed model can be useful for the analysis of three-dimensional structures subjected to dynamic and static loads but especially for the analysis of building structures, where mainly walls are responsible for the stiffness of the building. 


\section{The computational model}

\subsection{The model formulation}

The computational model is formulated on the basis of the finite element method in agreement with Zienkiewicz [8]. The discrete model is constructed using the subdivision of the structure into building elements such as wall and floor slab elements, plane and threedimensional joints (vertical and horizontal) and lintels [9] (Fig 2).

Wall and floor elements (Fig 3a), which are treated as vertical and horizontal strips, are described by deep beam scheme taking into account compression and twisting. Transverse section deformation is assumed as in Thimoshenko-type beam in agreement with [10].

The displacement field of wall and floor strips is expressed by

$$
\mathbf{f}_{\mathbf{w}}=\left\{\begin{array}{c}
u \\
v \\
w
\end{array}\right\}=\left\{\begin{array}{c}
u \\
0 \\
w_{0}
\end{array}\right\}+\left\{\begin{array}{c}
0 \\
x \psi \\
-x \varphi
\end{array}\right\},
$$

where: $\varphi$ - angle of rotation of the strip cross-section, $\psi$-angle of twist of the strip cross-section.

The strain field is written as

$$
\boldsymbol{\varepsilon}_{w}=\left\{\begin{array}{c}
\varepsilon_{x} \\
\varepsilon_{z} \\
\gamma_{z x} \\
\gamma_{z x}^{s}
\end{array}\right\}=\left\{\begin{array}{c}
\frac{u_{l}-u_{p}}{L} \\
\frac{\partial w}{\partial z} \\
\frac{\partial w}{\partial x}+\frac{\partial y}{\partial z} \\
2 y \frac{\partial \psi}{\partial z}
\end{array}\right\}=\left\{\begin{array}{c}
\frac{u_{l}-u_{p}}{L} \\
\frac{\partial w_{0}}{\partial z}-x \frac{\partial \varphi}{\partial z} \\
-\varphi+\frac{\partial\left(u_{l}+u_{p}\right)}{2 \partial z} \\
2 y \frac{\partial \psi}{\partial z}
\end{array}\right\}
$$

where: $l, p-$ two adjacent points between which strain is averaged, $L-$ distance between points $l$ and $p$ (width of the strip).

The strain vector has the form

$$
\boldsymbol{\varepsilon}_{\mathbf{w}}=\mathbf{L} \overline{\mathbf{f}}_{\mathbf{w}},
$$

where:

a)

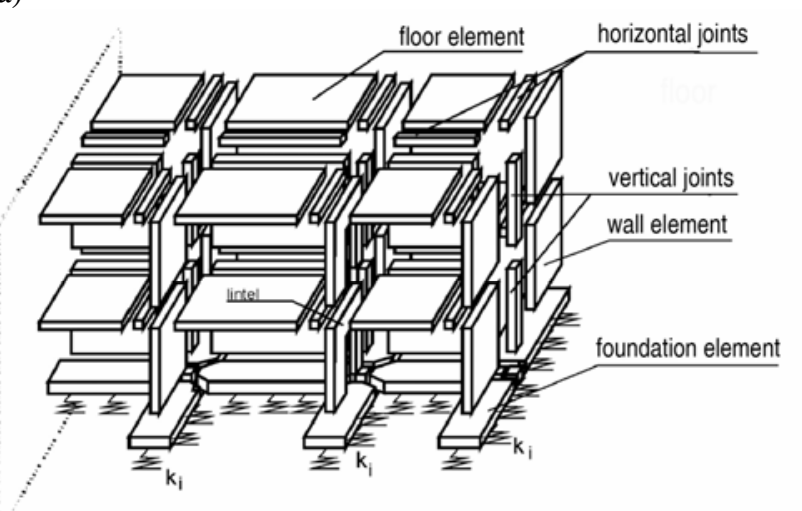

$$
\begin{aligned}
\mathrm{L} & =\left[\begin{array}{ccccc}
\frac{1}{L} & -\frac{1}{L} & 0 & 0 & 0 \\
0 & 0 & \frac{\partial}{\partial z} & -x \frac{\partial}{\partial z} & 0 \\
\frac{\partial}{2 \partial z} & \frac{\partial}{2 \partial z} & 0 & -1 & 0 \\
0 & 0 & 0 & 0 & 2 y \frac{\partial}{\partial z}
\end{array}\right], \\
\overline{\mathbf{f}}_{\mathrm{w}} & =\left\{\begin{array}{lllll}
\mathrm{u}_{l} & u_{p} & w_{0} & \varphi & \psi
\end{array}\right\} .
\end{aligned}
$$

The stress field is determined as follows:

$$
\boldsymbol{\sigma}=\mathrm{D} \varepsilon=\mathrm{D} \mathbf{L} \overline{\mathbf{f}}_{\mathbf{w}}
$$

where: $\mathbf{D}$ - constitutive matrix.

Plane and spatial joints are placed between floor and wall strips.

The displacement field in the plane joints (Fig 3c) can be expressed by:

$$
\mathbf{f}_{\mathbf{j}}=\left\{\begin{array}{c}
u \\
v \\
w
\end{array}\right\}=\left\{\begin{array}{c}
u \\
0 \\
w_{0}
\end{array}\right\}+\left\{\begin{array}{c}
0 \\
x \psi_{r} \\
-x \varphi_{r}
\end{array}\right\} .
$$

The strains can be calculated as follows:

$$
\boldsymbol{\varepsilon}_{\mathrm{j}}=\left\{\begin{array}{c}
\varepsilon_{x} \\
\gamma_{x z} \\
\gamma_{z x}^{s}
\end{array}\right\}
$$

where:

$$
\begin{gathered}
\varepsilon_{x}=\frac{\left(u_{l}-u_{p}\right)}{l_{n}}, \\
\gamma_{x z}=-\varphi_{r}+\frac{\partial u}{\partial z}=\frac{1}{l_{n}}\left(w_{l}-w_{p}\right)+\frac{\partial\left(u_{l}-u_{p}\right)}{2 \partial z}, \\
\gamma_{z x}^{s}=2 y \frac{\partial \psi_{r}}{\partial z}=2 y \frac{\partial\left(u_{l}-u_{p}\right)}{l_{n} \partial z},
\end{gathered}
$$

where: $\varphi_{r}-$ angle of rotation of the plane joint crosssection, $\psi_{r}-$ angle of twist of the plane joint crosssection, $l_{n}-$ width of the joint.

b)

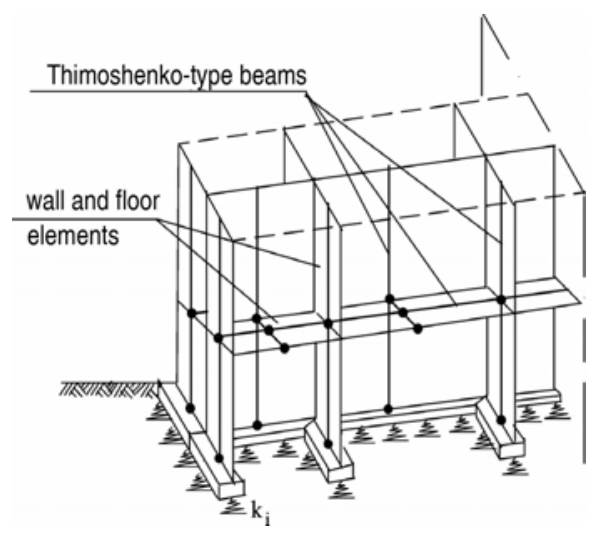

Fig 2. a) the subdivision of the structure, b) the location of Thimoshenko-type beams 
a)

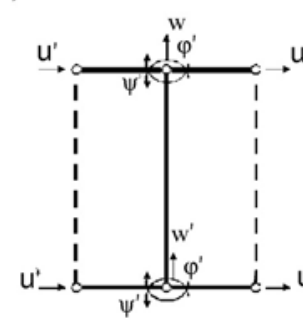

c)

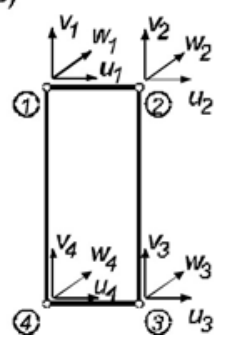

b)
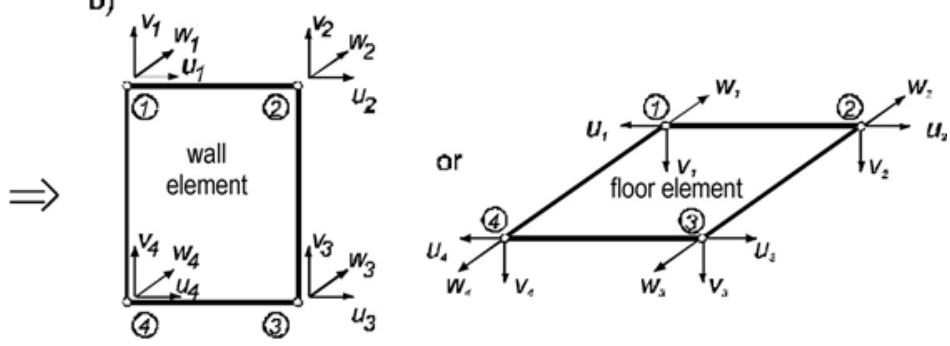

d)

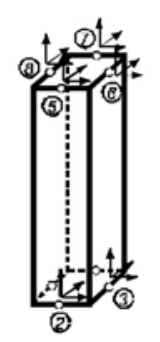

e)

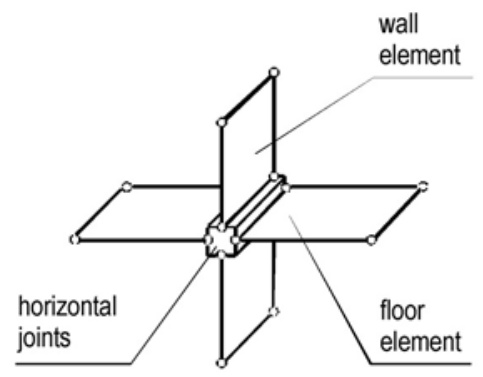

Fig 3. Elements of the computational model: a) basic wall element, b) wall element with unknowns in the corners,

c) plane joint, d) spatial joint, e) wall and floor elements interconnected by three-dimensional joints

Connection between 3 or 4 strips and 2 strips situated in a different plane is described by three-dimensional joint (Fig 3d, e). However, the displacement field of the spatial joints (Fig 3d) is assumed as in three-dimensional state of stress.

$$
\mathbf{f}_{\mathbf{j}}=\left\{\begin{array}{l}
u \\
v \\
w
\end{array}\right\}=\left\{\begin{array}{l}
u(x, y, z) \\
v(x, y, z) \\
w(x, y, z)
\end{array}\right\} .
$$

Strain field is calculated as

$$
\boldsymbol{\varepsilon}_{\mathbf{j}}=\left\{\begin{array}{c}
\varepsilon_{x} \\
\varepsilon_{y} \\
\varepsilon_{z} \\
\gamma_{x y} \\
\gamma_{y z} \\
\gamma_{x z}
\end{array}\right\}=\left[\begin{array}{ccc}
\frac{\partial}{\partial x} & 0 & 0 \\
0 & \frac{\partial}{\partial y} & 0 \\
0 & 0 & \frac{\partial}{\partial z} \\
\frac{\partial}{\partial y} & \frac{\partial}{\partial x} & 0 \\
0 & \frac{\partial}{\partial x} & \frac{\partial}{\partial y} \\
\frac{\partial}{\partial z} & 0 & \frac{\partial}{\partial x}
\end{array}\right] \mathbf{f}_{\mathbf{j}}=\mathbf{L}_{\mathbf{j}} \mathbf{f}_{\mathbf{j}} .
$$

Stress field can be described by

$$
\boldsymbol{\sigma}_{\mathbf{j}}=\mathbf{D} \boldsymbol{\varepsilon}_{\mathbf{j}}=\mathbf{D L} \mathbf{L}_{\mathbf{j}} \mathbf{j}_{\mathbf{j}}
$$

where:

$$
\mathbf{D}=\frac{E_{j}}{(1+v)(1-2 v)}\left(\mathbf{D}_{\text {diag }}+\mathbf{D}_{\mathbf{1 2}}\right)
$$

$$
\mathbf{D}_{\text {diag }}=\left[1-v, 1-v, 1-v, \frac{1-2 v}{2}, \frac{1-2 v}{2}, \frac{1-2 v}{2}\right],
$$

$\mathbf{D}_{12}-$ matrix $6 \times 6$, in which: $d_{12}=d_{13}=d_{21}=d_{23}=d_{31}=$ $d_{32}=v$; the other elements are equal 0 .

\subsection{The finite element method application}

The problem solution using the finite element method is reduced to a defined number of points, called nodes.

The unknown displacements distribution of wall and floor elements $\overline{\mathbf{f}}_{w}$ is expressed by:

$$
\overline{\mathbf{f}}_{w}=\mathbf{N} \mathbf{d}_{\mathbf{e}},
$$

where $\mathbf{N}$ - shape function matrix, $\mathbf{d}_{\mathbf{e}}-$ vector of unknown displacements at nodes of finite elements

$$
\mathbf{d}_{\mathbf{e}}=\left\{u_{l}^{i}, u_{p}^{i}, w^{i}, \varphi^{i}, \psi^{i}, u_{l}^{k}, u_{p}^{k}, w^{k}, \varphi^{k}, \psi^{k}\right\}^{T} .
$$

The equation of virtual work in dynamic problem is given by

$$
\begin{gathered}
\int_{t}\left\{\int_{V}\left[(\delta \boldsymbol{\varepsilon})^{T} \boldsymbol{\sigma}+(\delta \overline{\mathbf{f}})^{T}(\dot{\overline{\mathbf{f}}}+\rho \ddot{\overline{\mathbf{f}}})\right] d V\right\} d t- \\
\int_{t}\left\{\int_{V}(\delta \overline{\mathbf{f}})^{T} \mathbf{p}(\mathbf{t}) d V\right\} d t=0,
\end{gathered}
$$

where: $c$ - damping parameter, $\rho-$ mass parameter, $p(t)$ - changing load.

The equation (20), expressed by internal forces $\mathbf{W}$, has been obtained by formulas (3) and (4) and by integration of the equation (19)

$$
\begin{gathered}
\int_{t}\left\{\int_{h}\left[(\delta \overline{\mathbf{f}})^{T} \mathbf{L}^{T} \mathbf{W}+\mathrm{F}(\delta \overline{\mathbf{f}})^{T}(\mathbf{c} \dot{\overline{\mathbf{f}}}+\boldsymbol{\rho} \ddot{\overline{\mathbf{f}}})\right] d z\right\} d t- \\
\int_{t}\left\{\int_{h}\left[\mathrm{~F}(\delta \overline{\mathbf{f}})^{T} \mathbf{p}(\mathbf{t})\right] d z\right\} d t=0,
\end{gathered}
$$

where $\mathrm{F}$ - cross-sectional area.

$$
\mathbf{W}=\left\{\begin{array}{lllll}
N_{x} & N_{z} & Q_{z x} & M_{y} & M_{s}
\end{array}\right\} .
$$


Internal forces can be obtained by using FEM

$$
\mathbf{W}=\overline{\mathbf{D}} \mathbf{L} \overline{\mathbf{f}}=\overline{\mathbf{D}} \mathbf{L} \mathbf{N} \mathbf{d}_{\mathbf{e}}=\overline{\mathbf{D}} \mathbf{B} \mathbf{d}_{\mathbf{e}}
$$

where: $\overline{\mathbf{D}}$ - constitutive matrix, $\mathbf{N}$ - matrix of a shape function, $\mathbf{d}_{\mathrm{e}}-$ displacement vector of nodes.

Using equation (20) the typical system of differential equations can be obtained

$$
M \ddot{d}+\mathbf{C d}+K \mathbf{d}=\mathbf{P}(\mathbf{t}) \text {. }
$$

The solution of the equation (26) can be obtained by using one of well-known numerical method, ie indirect method (reduction and modal superposition) or direct method (Newmark and finite difference method).

In order to enable easier implementation of connections of finite elements, according to the presented model, the unknown displacements are transferred to the corners of elements (Fig 3b).

\subsection{Soil-structure interaction problem}

The subsoil is presented as elastic contact model described by spring constraints (Fig 4).

Taking into account structural elements, the displacements can be expressed as follows [11]:

$$
\begin{gathered}
u_{1}=u_{1}, \\
u_{p}=u_{2}, \\
w=\frac{w_{1}+w_{2}}{2}, \\
\varphi=\frac{w_{1}-w_{2}}{L}, \\
\psi=\frac{v_{1}-v_{2}}{L} .
\end{gathered}
$$

The forces of subsoil interaction have the form:

$$
\mathbf{K}_{\mathbf{f}} \mathbf{d}_{\mathbf{f}}=\mathbf{R}_{\mathbf{f}} \text {, }
$$

where:

$$
\begin{gathered}
\mathbf{K}_{\mathbf{f}}=\mathbf{K}_{\mathbf{f} \operatorname{diag}}+\mathbf{K}_{\mathbf{f} \mathbf{1 2}}, \\
\mathbf{K}_{\mathbf{f} \text { diag }}=\left[\begin{array}{llllll}
a & b_{1} & -c & a & b_{1} & -c
\end{array}\right], \\
\mathbf{d}_{\mathbf{f}}=\left\{\begin{array}{llllll}
u_{1} & w_{1} & v_{1} & u_{2} & w_{2} & v_{2}
\end{array}\right\}^{T}, \\
\mathbf{R}_{\mathbf{f}}=\left\{\begin{array}{lllllll}
R_{u_{1}} & R_{w_{1}} & R_{v_{1}} & R_{u_{2}} & R_{w_{2}} & R_{v_{2}}
\end{array}\right\},
\end{gathered}
$$

where: $\mathbf{R}_{\mathbf{f}}-$ forces of subsoil interaction, $\mathbf{K}_{\mathbf{f}} \mathbf{1 2}-$ matrix $6 \times 6$ in which: $k_{25}=k_{52}=b_{2}, k_{36}=k_{63}=c$ and the other elements equal 0 .

$$
\begin{aligned}
& a=\frac{1}{2} F_{f} k_{u}, \\
& b_{1}=\frac{1}{4} F_{f} k_{w}+\frac{1}{L^{2}} J_{f} k_{w}, \\
& b_{2}=\frac{1}{4} F_{f} k_{w}-\frac{1}{L^{2}} J_{f} k_{w}, \\
& c=\frac{1}{L^{2}} J_{0} k_{v} .
\end{aligned}
$$

$\mathrm{F}_{\mathrm{f}}, \mathrm{J}_{\mathrm{f}}, \mathrm{J}_{0}$ - cross-sectional area and moments of inertia of the foundation footing, $k_{\mathrm{u}}, k_{\mathrm{v}}, k_{\mathrm{w}}$ - proportional subsoil coefficients [12].

Taking into account the subsoil, the computational model has a form:

$$
\begin{aligned}
& {\left[\begin{array}{cc}
\mathbf{M}_{11} & \\
\mathbf{M}_{22}
\end{array}\right]\left\{\begin{array}{l}
\ddot{\mathbf{u}}_{\mathbf{k}} \\
\ddot{\mathbf{u}}_{\mathbf{f}}
\end{array}\right\}+\left[\begin{array}{ll}
\mathbf{C}_{11} & \\
{\left[\begin{array}{ll}
\mathbf{K}_{11} & \mathbf{K}_{12} \\
\mathbf{K}_{21} & \mathbf{K}_{22}+\mathbf{K}_{\mathbf{f}}
\end{array}\right]\left\{\begin{array}{l}
\mathbf{u}_{\mathbf{k}} \\
\mathbf{u}_{\mathbf{f}}
\end{array}\right\}=\left\{\begin{array}{l}
\mathbf{u}_{\mathbf{k}} \\
\mathbf{u}_{\mathbf{f}}
\end{array}\right\}+} \\
\mathbf{P}_{\mathbf{f}}
\end{array}\right\},}
\end{aligned}
$$

where: $\mathrm{k}$ - degree of freedom of the structure, $\mathrm{f}$ - degree of freedom of the contact zone between structure and subsoil. a)
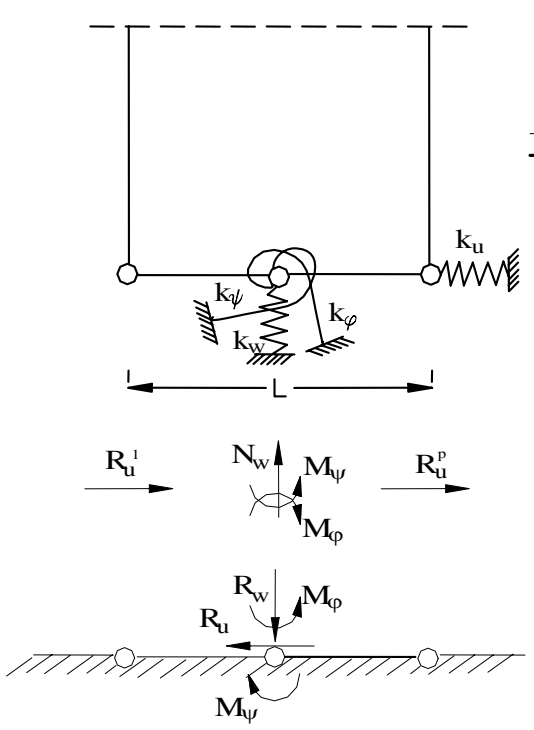

b)
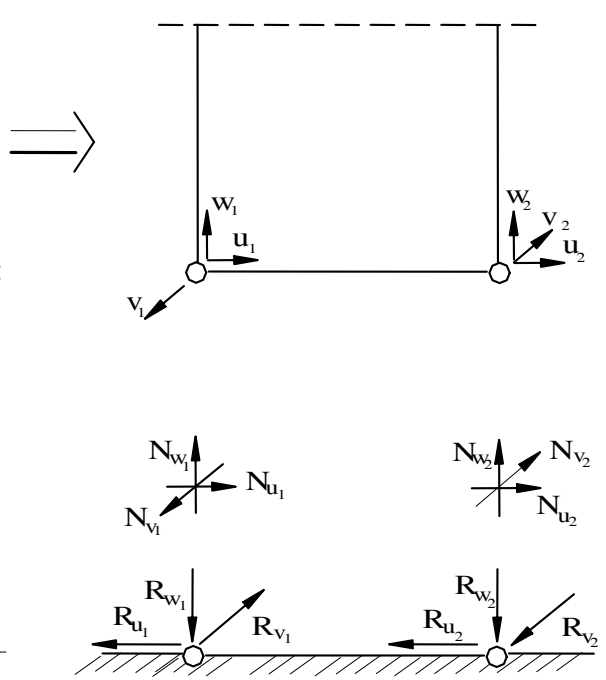

Fig 4. The subsoil interaction in the elastic contact model: a) elastic constrains, b) soil-structure interaction 


\subsection{The model loads}

In case of problems changeable with time the system of differential equations (23), (25) is to be solved.

The equation of motion for kinematic loads transferred from subsoil to building structure has the form:

$$
\mathbf{M}\left(\ddot{\mathbf{d}}+\ddot{\mathbf{d}}_{\mathbf{g}}\right)+\mathbf{C} \dot{\mathbf{d}}+\mathbf{K d}=0,
$$

where: $\mathbf{M}$ - inertia matrix, $\mathbf{C}$ - damping matrix.

In case of "step by step" method of integration the $\mathbf{C}$ matrix is often exchanged by combination of inertiastiffness damping:

$$
\mathbf{C}=\alpha \cdot \mathbf{M}+\beta \cdot \mathbf{K}
$$

$\alpha, \beta$ - coefficients, $\mathbf{K}$ - stiffness matrix, $\ddot{\mathbf{d}}$ - acceleration vector, $\mathbf{d}$ - velocity vector, $\mathbf{d}$ - displacement vector, $\ddot{\mathbf{d}}_{g}$ - equivalent acceleration vector of vibrations transferred from subsoil to building structure.

$$
\ddot{\mathbf{d}}_{g}=\sum_{i} a_{g}^{i} \cdot \mathbf{T}_{\mathbf{i}},
$$

$\mathbf{T}_{\mathbf{i}}-$ transformation vector for i-direction of vibration, $a_{g}{ }^{i}-i$-component of building footing acceleration.

Because the acceleration components $a_{g}{ }^{i}$ are known from recorded vibration accelerograms, the equation (36) has now the form:

$$
M \ddot{d}+C \dot{d}+K d=-M \ddot{d}_{g}=P(t) .
$$

\section{Numerical tests}

The numerical tests present the verification of the correctness, accuracy and efficiency of the proposed computational model by comparison with the results obtained by using classic finite elements. The correctness of the presented elements has been estimated according to the principals used in FEM [8]. Both described in the paper new elements and classic finite elements have been implemented into the author's software "ORCAN" (kmb.pb.bialystok.pl/dydaktyka/tchyzy).
The dynamic response of the building models have been tested under paraseismic impact load. The results have been compared taking into account displacements and computational time.

\subsection{Numerical test No 1}

Test No 1 concerns the single segment of the 11-storey building (large-panel building technology). Concrete of B-20 class (according to Polish standards and C16/20 according to EC2) has been used for walls and floors of $14 \mathrm{~cm}$ thickness. Fig 5 a shows the horizontal projection of the segment, Fig $5 \mathrm{~b}$ - the computer model of the building which consist of elements proposed in the paper. The dynamic response of the building model has been tested under paraseismic impact load which had been registered on mining area of industrial complex KGHM "Polska Miedz" in Polkowice (Poland). Fig 6 shows the accelerogram. The kinematic load used in the analysis corresponds to the results obtained from the measurements of the building foundation. The load direction is in $\mathrm{Y}$ axis (Fig 5).

The computations have been carried out by using the author's software "ORCAN".

Figs 7 and 8 present the analysis results:

- MQDES(H) - analysis has been carried out by using "ORCAN" and elements presented in the paper. System discretisation correspond to the natural division of the building structure into wall and floor elements.

- ORCAN - analysis has been carried out by using "ORCAN" with 4-node shield elements and 4-node plane elements. The results have been obtained by concentration of mesh 1,2 and 4 times in both plane directions what correspond to the division into 1,4 and 16 elements in comparison with the natural division into wall or floor elements. a)

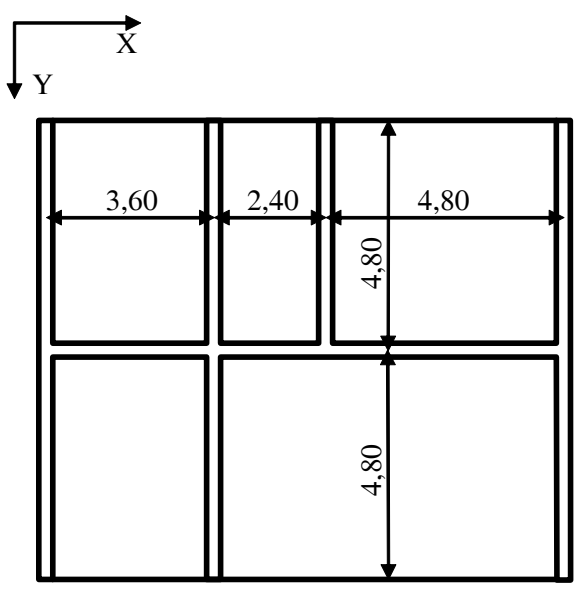

b)

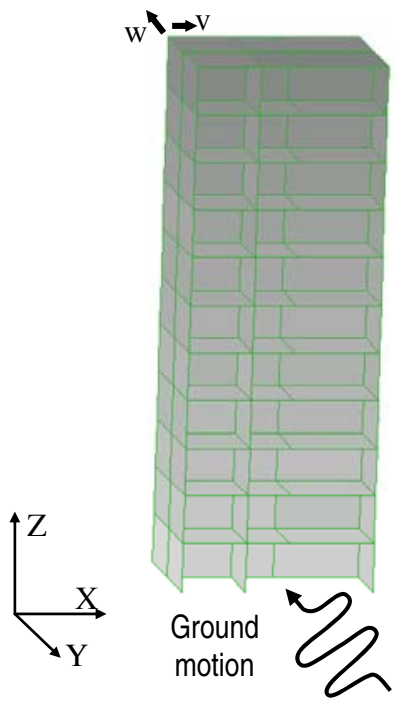

Fig 5. Segment of the building: a) the horizontal projection, b) computer model 
Fig 7 shows the response in the form of displacements $w$ of segment top (without damping). Fig 8 presents the response in the form of displacements $v$ of segment top (without damping). The denotations ORKAN-1, -2, -4 concern the mesh concentration by using classic shield-plate finite elements what correspond with the division into 1, 4 and 16 elements in comparison with the natural division into wall or floor elements.

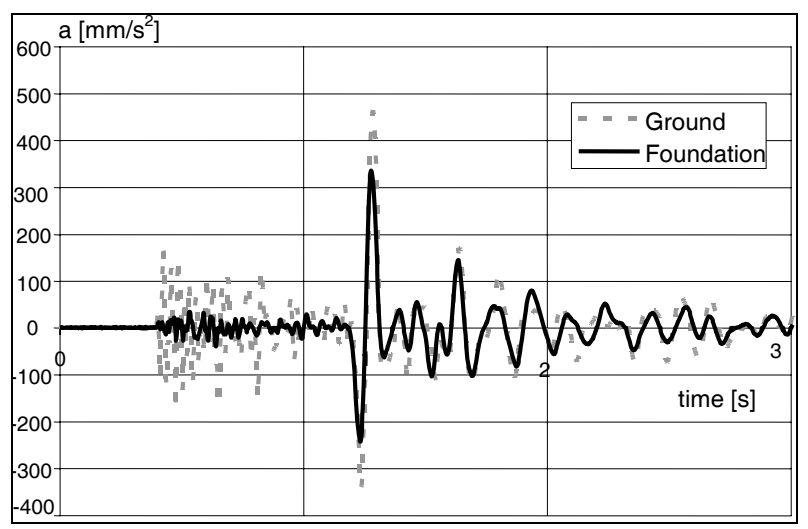

Fig 6. Diagram of acceleration - Polkowice 13-01-2000

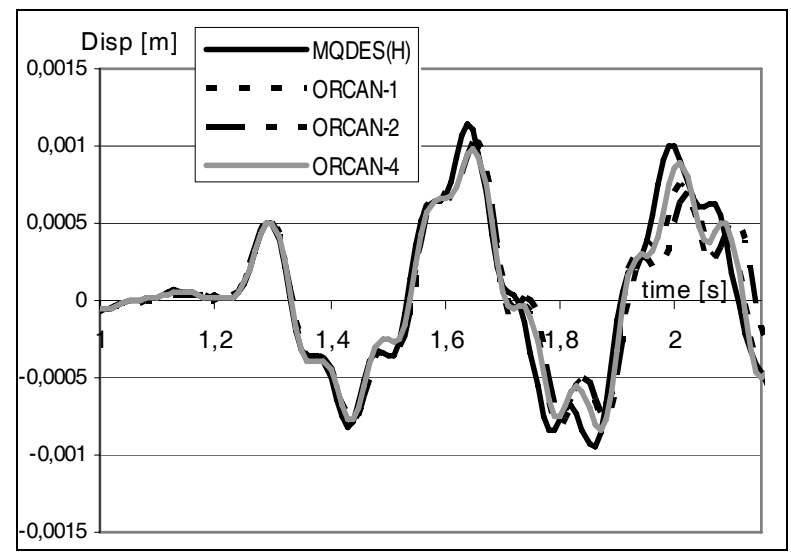

Fig 7. Displacements diagram of the top of the segment in $w$ direction

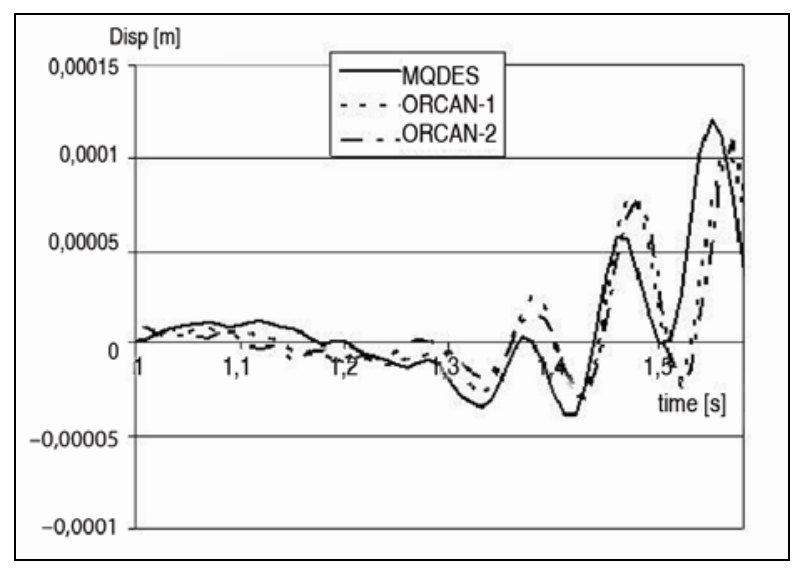

Fig 8. Displacements diagram of the top of the segment in $v$ direction
Table 1 presents computational times of the analysis, where:

- Newmark method has been used for the integration if motion equations and the elements stiffness matrices have been determined in every time step,

- damping has been omitted,

- number of integration steps NSTEP $=1500$,

- shield-plate elements have been integrated numerically: Gauss points number $-3 \times 3$, number of degree of freedom -20 .

Table 1. Analysis of computational times

\begin{tabular}{|c|c|c|}
\hline \multicolumn{2}{|l|}{ Method } & Computational time [s] \\
\hline \multicolumn{2}{|c|}{1} & 2 \\
\hline MQDivision & & 70 \\
\hline \multirow{3}{*}{ ORCAN } & 1 & 930 \\
\cline { 2 - 3 } & 1 & 3727 \\
\cline { 2 - 3 } & 2 & 14889 \\
\hline
\end{tabular}

This test shows that proposed model which used MQDES elements can well describe dynamic response of the building and can provide accurate results with significantly reduced computational time.

\subsection{Numerical test No 2}

Fig 9 shows the 4-storey building erected in the same technology as structure in test No 1 . The building consists of 3 identical segments.

The dynamic response of the building has been tested under paraseismic impact load showed in Fig 9. The load direction is in Y axis (Fig 9). Fig 10 presents the response in the form of displacements $w$ of segment top (without damping). Fig 11 shows the response in the form of displacements $v$ of segment top. The denotations ORKAN-1, -2 concern the mesh concentration by using classic shield-plate finite elements what correspond with the division into 1 and 4 elements in comparison with the natural division into wall or floor elements.

Table 2 presents computational times of the analysis, where:

- Newmark method has been used for the integration of motion equations, and the elements stiffness matrices have been determined in every time step,

- damping has been omitted,

- number of integration steps NSTEP $=5000$,

- shield-plate elements have been integrated numerically: Gauss points number $-3 \times 3$, number of degree of freedom -20 .

Table 2. Analysis of computational times

\begin{tabular}{|c|c|c|}
\hline \multicolumn{2}{|c|}{ Division } & Computational time [s] \\
\hline \multicolumn{2}{|c|}{1} & 2 \\
\hline MQDES & 1 & 171 \\
\hline \multirow{2}{*}{ ORCAN } & 1 & 1750 \\
\hline & 2 & 5206 \\
\hline
\end{tabular}




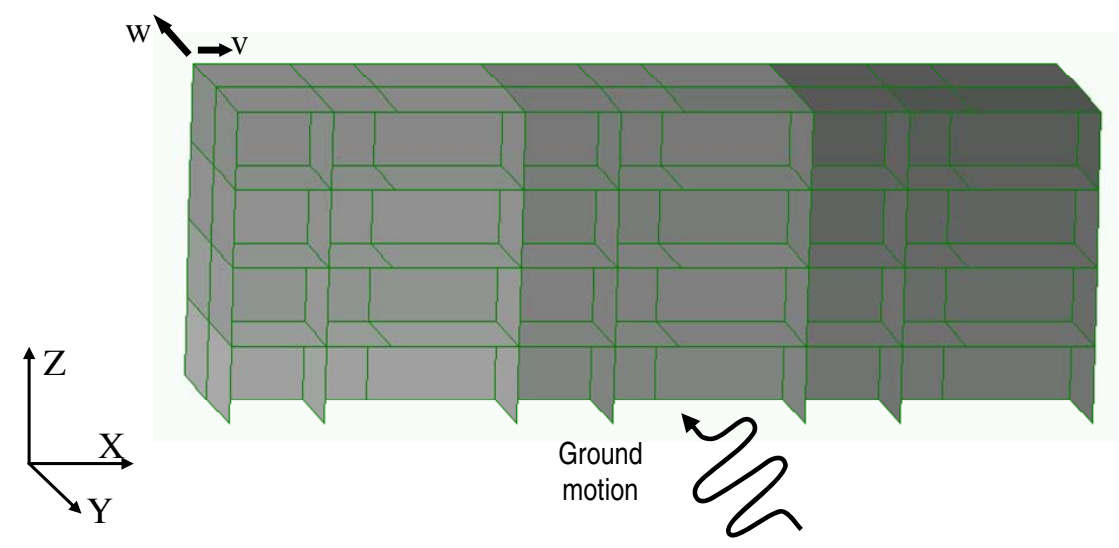

Fig 9. Computational model of the building

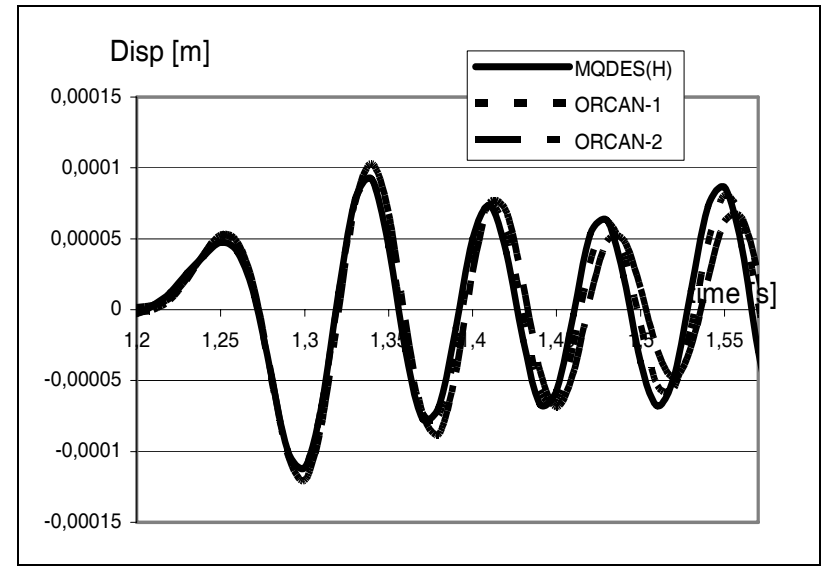

Fig 10. Displacements diagram of the top of the segment in $w$ direction

This test proved that proposed model which used MQDES elements can well describe dynamic response of the building and can provide accurate results with significantly reduced computational time.

\subsection{Example of practical application}

Computational example No 3 shows the real application of the presented model - the results of the dynamic computations of the building located in the mining area.

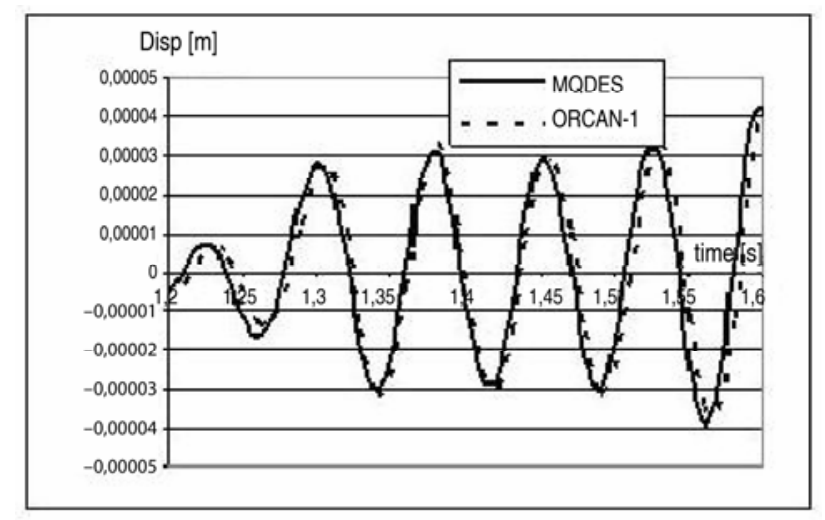

Fig 11. Displacements diagram of the segment top in $v$ direction

Fig 12 presents the building erected in WWT technology. The building consists of 7 habitation segments and 4 separated staircases (KL).

The staircases are the subject of the analysis. Building has been subjected to kinematic load in the form of subsoil vibrations on the mining area Fig 13 b). In Fig 14 the eigenvalues and their vibration forms have been presented.

Fig 15 shows the horizontal displacements diagrams, where P4, P8 and P11 are the displacements appropriately at the level of 4,8 and 11 ceiling.

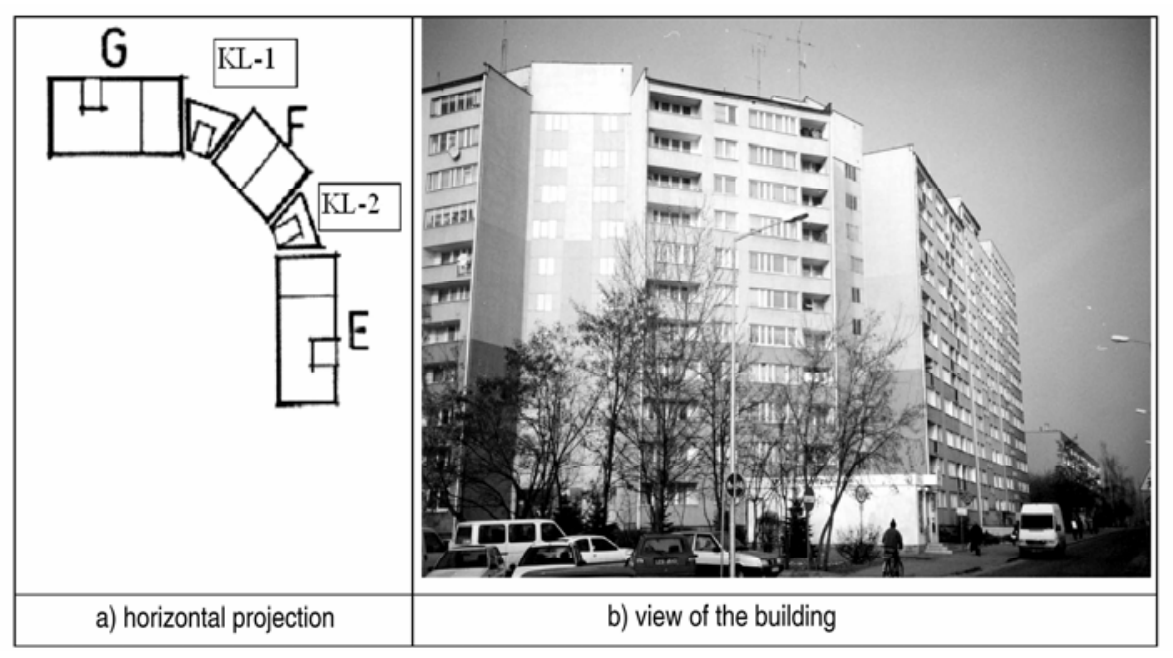

Fig 12. Staircase location 


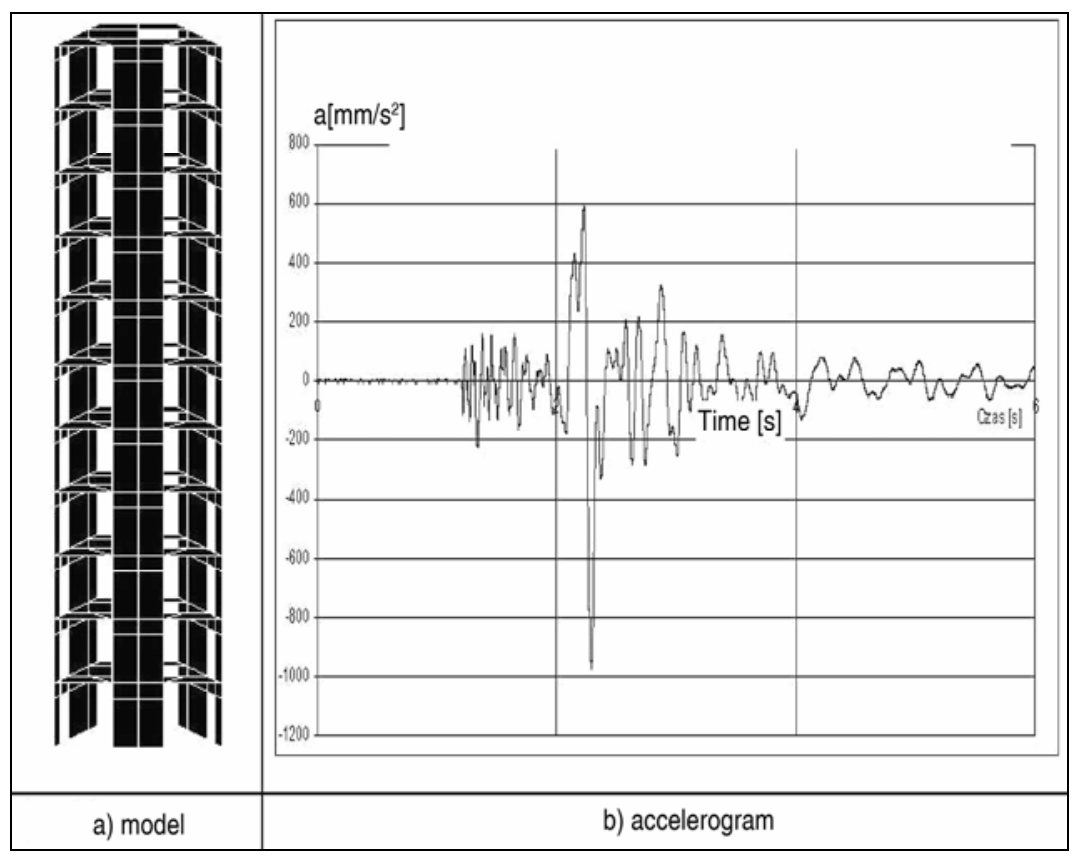

Fig 13. Computational model of the single staircase and its foundation acceleration

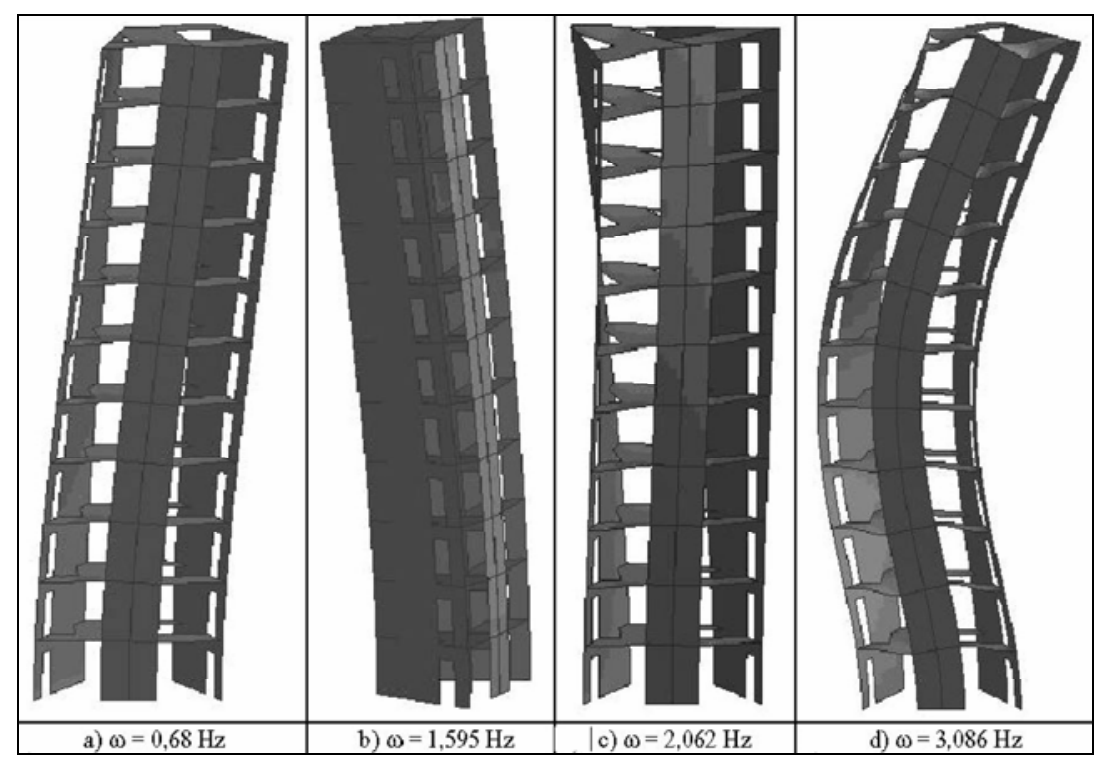

Fig 14. Free vibration forms

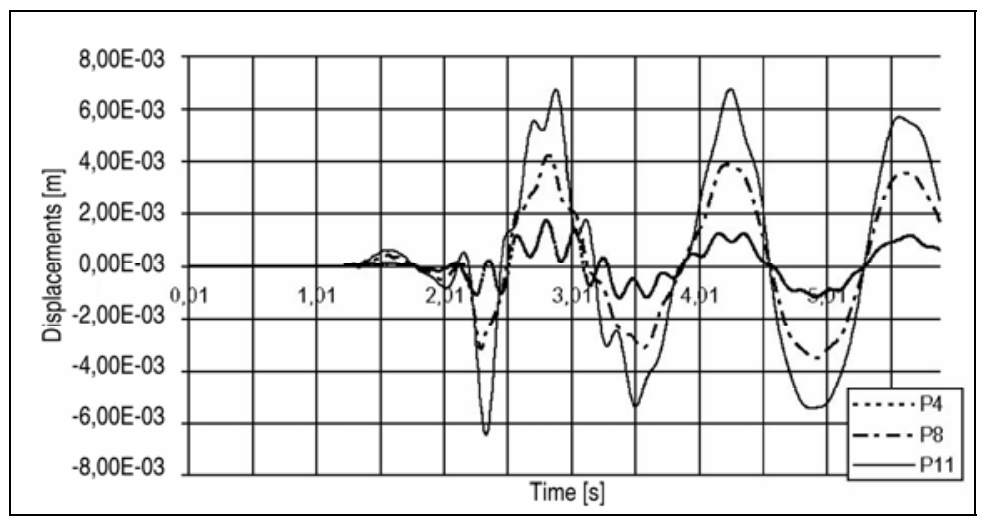

Fig 15. Horizontal displacements diagram 


\section{Conclusions}

The presented method opens possibilities for the modelling and discretisation of complex threedimensional building structures. The model is assembled of elements corresponding to the division of a real structure into constituent elements, i e wall panels, floor slabs, plane and spatial joints as well as lintels. The description of stiffness changes, which is determined at the level of the individual cross-sectional areas of the building elements, does not increase the number of unknowns. Such a modelling and description of stiffness changes allow to create a computational model with a comparatively small number of unknowns.

Because of the small number of unknowns the dynamic analysis of large building structures in threedimensional scheme can be carried out easily in relatively short time on commonly used hardware of PC class (the computational time is from dozens to several-hundreds times less in comparison with the commercial software).

Numerical tests have confirmed the correctness and usefulness of the presented method for the analysis of complex structures subjected to kinematic load.

This model can be very useful for scientific research and code verification purposes, for testing simple computational models, for structural designing in complicated load and soil conditions, for carrying out expertises or for modernisation existing building systems.

\section{References}

1. CHOLEWICKI, A.; CHYŻY, T. and SZULC, J. Verification of computation methodology for buildings exposed to mining tremors. In Proc of the 11th International Con- gress of the International Society for Mine Surveying, Cracow, 2000, p. 497-505.

2. KIM, H. S. and HONG, S. M. Formulation of transition elements for the analysis of coupled wall structures. Computers and Structures, 57 (2), 1995, p. 333-344.

3. KIM, H. S. and LEE, D. G. Analysis of shear wall with openings using super elements. Engineering Structures, 25 (8), 2003, p. 981-991.

4. KIM, H. S. and LEE, D. G. Efficient analysis of flat slab structures subjected to lateral loads. Engineering Structures, 27 (2), 2005, p. 251-263

5. CHOI, C. K.; KIM, S. H.; PARK, Y. and CHEUN, K. Y. Two-dimensional nonconforming finite elements: A stateof-art. Structural Engineering and Mechanics, 6(1), 1998, p. 41-61.

6. CHOI, C. K.; LEE, P. S. and PARK, Y. M. Defect-free 4-node flat shell element: NMS-4F element. Structural Engineering and Mechanics, 8(2), 1999, p. 207-231.

7. LEE, D. G.; KIM, H. S. and CHUN, M. H. Efficient seismic analysis of high-rise building structures with the effects of floor slabs. Engineering Structures, 24 (5), 2002, p. 613-623.

8. ZIENKIEWICZ, O. C. The finite element method. McGraw-Hill, 1986. 787 p.

9. MIEDZIALOWSKI, Cz. Three-dimensional modelling of wall structures. Archives of Civil Engineering, XLI (2), 1995, p. 195-212.

10. THIMOSHENKO, S. P. and GOODIER, J. N. Theory of elasticity. McGraw-Hill, New York, 1951. 608 p.

11. MIEDZIALOWSKI, Cz. Discrete model of complex threedimensional structural schemes of buildings taking into account soil-structure interactions. Research report No 24, Białystok, 1994. 283 p. ( in Polish).

12. SELVADURAI, A. P. S. Elastic analysis of soilfoundation interaction. Elsevier, 1979. 543 p.

\section{ERDVINIŲ PASTATU SKAITINIS MODELIAVIMAS}

\section{Cz. Miedziałowski, T. Chyży, J. Krętowska}

Santrauka

Trimačio pastato modelio analizè, ivertinant statinio ir grunto sąveiką, yra labai sudėtingas uždavinys. Jis sprendžiamas taikant baigtinių elementų metoda. Tačiau, tiesiogiai taikant ši metoda, reikia didelio kompiuterio pajègumo bei laiko sąnaudų. Todèl pasiūlytas hierarchinis skaičiuojamasis modelis šioms trimatėms problemoms spręsti. Šiame modelyje pastatas dalijamas i statybinius elementus, tokius kaip sienų ir perdangų plokštès, dvimačiai bei trimačiai mazgai, sąramos. Taikant ši modeli, gaunami tikslūs rezultatai, kartu gerokai sutrumpinamas skaičiavimo laikas. Pateikti pavyzdžiai iliustruoja pasiūlyto modelio galimybes bei efektyvumą.

Reikšminiai žodžiai: trimačiai pastatų elementai, superelementai, dinaminė uždavinio formuluotė, baigtinių elementų metodas.

Czeslaw MIEDZIAŁOWSKI. Professor, Chair of Structural Mechanics, Institute of Civil Engineering at the Bialystok Technical University (Poland), Dr Habil. Member of Computer Methods Association, Polish Society of Theoretical and Applied Mechanics, Polish Civil Engineers and Technicians Association. His research interests include problems of soilstructure interaction and computer analysis of building structures.

Tadeusz CHYŻY. Associate Professor, the Chair of Structural Mechanics, Institute of Civil Engineering at the Bialystok Technical University (Poland), where he received his PhD degree. Member of Scientific Committee of Polish Civil Engineers and Technicians Association. His research interests include the structures behaviour under seismic and paraseismic impacts, problems of gas explosions in the building structures and utilisation of computer methods for structural analysis.

Joanna KRETOWSKA. Associate Professor, the Chair of Structural Mechanics, Institute of Civil Engineering at the Bialystok Technical University (Poland), where she received her PhD degree. Member of Polish Civil Engineers and Technicians Association. Her research interests include problems of soil-structure interaction and computer methods in structural analysis. 